\title{
Discrimination against Female and Widow in Inheritance of Real Estate and Succession in the South Eastern Nigeria: A Breach of International Instrument and the Nigeria Constitution
}

\author{
Hilary Nwaechefu. LL.B, LL.M BL, \\ Doctoral Research Candidate,University of Ibadan; Lecturer Faculty of law,Redeemer's University, Ede Osun \\ state Nigeria; Adjunct Lecturer, General Studies Department, Lagos State Polytechnic, Ikorodu Lagos Nigeria \\ Stephen Timiebiowei Kalama. LLB, MA, BL, \\ College of Health Technology, Otuogidi-OgbiaYenegoa,Bayelsa state Nigeria
}

\begin{abstract}
There is no doubt that the issue of the right of a female child or a widow to inheritance and succession among the Igbo nation in the South Eastern part of Nigeria is somewhat disturbing to every kind and compassionate human heart. There has not been any specific local legislation addressing issues arising on the mode of inheritance and succession in the south eastern Nigeria when a man dies intestate. This paper critically looked at the dilemma and plights of women when their fathers or husbands die intestate among the Igbo nation in the South Eastern part of Nigeria. This paper relied on judicial decisions, as well as relevant text and articles on the subject of female right to inheritance. This paper noted that despite several judicial decisions giving females the right to inheritance, a lot of enlightenments and other steps enunciated by this paper need to be embarked upon to see that the female child or a widow is no longer excluded or marginalized in property inheritance.This paper recommends amongst other things, the need for domestication in the various Houses of Assembly in south Eastern Nigeria, the judgments of the Apex court that gave females the right toinheritance during intestacy of either father or husband as the case may be.
\end{abstract}

Keywords: succession, inheritance, customary law, real estate, intestacy.

DOI: $10.7176 / J L P G / 81-06$

\section{Introduction}

The concept of the right of a female child or a widow to inheritance and succession among the Igbo nation in the South Eastern part of Nigeria have become topical, important, and perhaps notorious depending on your point of view. Lawyers, sociologists, religious bodies and social commentators have shed varying opinions on issue of the female right to inheritance of property. Judges alike have made conflicting judicial pronouncements on the all-important subject of right of a female child or a widow to inheritance. Many writers in the past and present notably Professor E I Nwogugu (1974) ${ }^{1}$, Professor Itse Saggay ( 2014) ${ }^{2}$, Professor Toriola Oyewo (1999) ${ }^{3}$, among others have dwelt on this subject matter of the right of a female child or a widow to inheritance and succession. The Supreme Court of Nigeria has in recent time been confirming the position that a female child or a widow has the constitutional backing not to be discriminated against on the ground of God instituted gender differentials. There is no doubt that following recent judgments of the Supreme Court of Nigeria, it is actionable at the competent court of law for a female to be excluded in partitioning of the property of a man who dies intestate. Imo state government in Nigeria had recently passed legislation entitling women to inheritance of their late father's estate. However no legislation had been passed by the Federal Parliament in Nigeria entitling women to inheritance of their late father's estate; nevertheless the constitutional provisions of the Federal Republic of Nigeria 1999 as amended and the recent judgments of the Supreme Court of Nigeria serves are useful reference points when the need arises. There is no doubt that a discussion of this nature will serve the immediate and future needs for advancement of Nigeria legal jurisprudence.

\section{Definition of Key Concepts}

Black's Law Dictionary ${ }^{4}$ defines human right thus: "The freedom, immunities and benefits that, according to modern value (Esp. at international level) all human beings should be able to claim asa matter of right in the society in which they live"

From the two definitions supplied from the Black's Law Dictionary, one can deduce that the concept of human right is of global application which every country that observes rule of law must embrace.

\footnotetext{
${ }^{1}$ Nwogugu, E.I ( 1974) family law in Nigeria, Heinemann educational books p.1xxxi

${ }^{2}$ Sagay (2006) Nigeria law of succession ,malthouse Press limited

${ }^{3}$ Oyewo, T (1999) a hand book on African laws of marriage, inheritance and succession, Jator publishing co.

${ }^{4}$ Edited by Bryan A Garner809 (Ninth ed. 2004)
} 
Inheritance is defined thus ${ }^{1}$ :

"Property received from an ancestor under the laws of Intestacy. Property that a person receives by bequest or device

Succession is defined thus ${ }^{2}$

'The acquisition of right or property by inheritance under the law of descent and distribution',

Intestatelaw is defined thus ${ }^{3}$ :

"The relevant statute governing succession to estate of those who die without a valid will"

From the Black's Law dictionary definitions stated above, Inheritance and Succession when used under the context of the customary law in Nigeria could safely be defined as the right to acquire the property of one's late parents who died without a will, that is, intestacy.

\section{Legal frame work of this article}

i. Universal Declaration of Human rights (1948)

ii. Convention on Elimination of all forms of discrimination against Women (1981)

iii. Constitution Federal Republic of Nigeria 1999 as amended

Universal Declaration of Human rights (1948), under Article 7, it states thus:

"All are equal before the law and are entitled without any discrimination to equal protection of the law. All are entitled to equal protection against any discrimination in violation of this Declaration and against any incitement to such discrimination",

ii. Convention on the Elimination of All Forms of Discrimination against Women (1981) with protocol 2000. Article 16 (vi) provides for Respective rights in matters of property and succession.

Article 5 enjoins state parties to take all appropriate measures to modify the social and cultural pattern of conduct of men and women, with a view to achieving the elimination of prejudices and customary and all other practices which are based on the idea of the inferiority and the superiority of either of the sexes or on stereotyped roles for men and women

iii. Constitution Federal Republic of Nigeria 1999 as amended.

Section 42(1) provides: "A citizen of Nigeria of a particular community, ethnic group, place of origin, sex, religion or political opinion shall not by reason only that he is such a person:

(a) Be subjected either expressly by, or in the practical application of, any law in

(b) force in Nigeria or any executive or administrative action of the government, to disabilities or restrictions to which citizens of Nigeria of other communities, ethnic groups, places of origin, sex, religion or political opinions are made subject: or ,.. No citizen of Nigeria shall be subjected to any disability or deprivation merely by reason of the circumstances of his birth."

The three instruments under reference to wit: i. Universal Declaration of Human rights (1948)

ii. Convention on Elimination of all forms of Discrimination against Women (CEDAW) (1981) iii. Constitution Federal Republic of Nigeria 1999 as amended; all clearly condemn all forms of discriminations against persons by reason of sex, race or nationality.

If these instruments are anything to go by, then the discriminatory practice in the south eastern part of Nigeria against females and widows in the area of property inheritance and right to succession when their fathers or husbands die intestate should not arise in this dispensation.

In the light of these three instruments highlighted above, we will move on to examine the inheritance practice and succession practice among the people in the south east of Nigeria, bringing to bare the obnoxious practices against the female gender.

Inheritance practice and succession practice among the Igbo people in the south Eastern part of Nigeria which breached the rights of women

This article is focused on the south eastern part of Nigeria, which of course, is made up five states out of the thirty six states in Nigeria. The five states include Imo, Anambra, Abia, Ebonyi, Enugu states. These five states speak a native language referred to as 'Igbo' but the official language remains English. We also have some parts of Delta such as Aniocha, Okwushiuku, Ibusa who speak the Igbo language or languages so similar to that of the Igbo nation. In River state in Nigeria, we also have people from Ikwere, Ahoada, Andoni who also speak Igbo language or languages so similar to the Igbo nation. However the origin of the Igbo speaking people in Delta state and Rivers state have not been confirmed to be the same with that of the Igbo people in south easternNigeria.

\footnotetext{
'Black’s Law dictionary Ninth Ed. Edited By Bryan A Garner. p.853

${ }^{2}$ ibid p. 1569
}

3ibid p.508 
The Igboculture on inheritance and succession follows the primogeniture principle, whereby the first male child succeeds his father at the latter's demise. The people of Benin kingdom in Edo state in nigeria also practice the primogeniture culture. Suffice it to say, we are going to concentrate on the Igbo nation of thesouth eastern Nigeria in this article.

By the concept of primogeniture as practiced by the people Igbo origin, the first born male child succeeds the headship of his family after the father's demise, to the exclusion of his other male and female siblings. The Igbo tribe refers to the eldest male child as "Diokpala or simply Okpala". In the nuclear family setting, the eldest son of a deceasedsucceeds him and rules over his father's immediate family, notwithstanding the fact that some female children of his late father may by far be older than him. In the extended family, where there are several heads of several nuclear families, the eldest man of all the nuclear families becomes the head of the family and is also referred to as the Diokpala of the extended family. The other nuclear family heads pay allegiance to the head or the Diokpala of the extended family. This Diokpala of the extended familymay as well be the youngest child among several female children in the family, as for instance where the older males die in a war battle or even in auto crash or plane crash. No woman can step in as the head of the family ${ }^{1}$.

The Igbo ethnic group go by their ancestral name as surname, that is to say, the first man that started the family, his name automatically becomes the surname of the family members from generation to generation, except perhaps a member, for any reason rebels and voluntarily stops using the family name. When this occurs, which rarely occurs though, the other members will appeal to him to revert to the common family name for which everybody knows the family. Whenever this family founder dies, it is his first male child that customarily steps into his shoes as the new head of the family. This new head of the family will continue with the surname already in place. He also takes over the family 'god' exemplified by an idol and performs the needed sacrifice so that the god will continue to protect the family here on earth. This family object of worship is called "ofor" in Igbo dialect.

Whenever a head of family dies intestate, the first son inherits his clothes, regalia, personal cars and personal dwelling place called "obi" to the exclusion of deceased brothers and widows. The first son exclusively inherits his father's farming tools and his livestock, if any and the father's immediate surrounding compound ${ }^{2}$. The money of the intestate father is inherited by all his male children to the exclusion of the females, no matter the number of the females or biological ages.

The position of the first son is so important and sacred that a portion of the family property is specially allocated to him for habitation and for farming purposes as the head of the family. ${ }^{3}$ After the head of the family, the other male children of the deceased head of family will thereafter take their turn and share in their late father's estate to the exclusion of the female children ${ }^{4}$. Where the deceased head of the family had no male child, his properties would be inherited by the eldest of his blood brothers and nobody disputes it.

It is unheard of, that a female child or a widow under Igbo native law and custom will inherit her late father or late husband's landed property, let alone taking over the headship of the family of her late father or late husband under Igbo customary law. To buttress this assertion is the case of Ugboma v Ibeneme \& anor. ${ }^{5}$ In that case, one Rev. Ibeneme, a native of Awkuzu in Anambra Local government Area in Anambra state Nigeria died intestate, leaving a number of landed property at Onitsha including No. 44, New Market Road, he was survived by two sons and several daughters. The plaintiffs are the second son and six of his sisters. The first defendant is the eldest son and head of late Rev. Ibeneme's family. The first defendant sold and conveyed No. 44, New Market Road, Onitsha in Anambra state to the $2^{\text {nd }}$ defendant. The issue before the court was whether the first defendant is entitled to sell and convey the said property to the $2^{\text {nd }}$ defendant to the exclusion of the plaintiffs. The plaintiffs in the pleadings sought the following reliefs: 1. A declaration that the property in question, being the joint property of all the children of Ibeneme, could not be sold and conveyed by the first defendant alone. 2 . An order of the honourable court setting aside the sale, the deed of conveyance and 3, An order that the second defendant should account for the proceeds of the sale. The learned trial judge, Egbuna J., held that, towing the line of the laid down Igbo custom, women are not entitled to inherit landed propertyof their father.

This custom is really an unfortunate one for the Igbo woman; but none the less, the daughter of a deceased must be maintained by whoever inherited her late father's estate until the daughter becomes an independent adult or whenever she marries or dies which ever event first occurs. For as long as the daughter remains unmarried, she has the right to be given a portion of the family land for her to farm until she marries, or dies. ${ }^{6}$

The position of the eldest son called "Okpala" in most part of the south eastern states of Nigeria is that, apart from inheriting the living home of his father referred to as 'Obi' inIgbo dialect, he also holds the other

\footnotetext{
Nwogugu,E.I family law in Nigeria, Heinemann educational books p.1xxxi. p 401,(1974)

${ }^{2}$ Nwafia V Ububa 1 All NLR 8(1966)

${ }^{3}$ Obi SNC the customary law manual, government printer, Enugu. p.136, (1977)

4 ibid. pp 100-109

${ }^{5}$ E.N.L.R p.252 (1967)

${ }^{6}$ Obi op. p 103
} 
family property in trust for himself and his other brothers, for whom he is expected to ensure that there is equitable distribution of the family property ${ }^{1}$. These properties are distributed to the exclusion of the females, no matter how many females are in the family. The proceeds from any property let out from the family property must also be shared by the eldest son and younger brothers to the exclusion of the females ${ }^{2}$.

In customary law generally, inheritance is said to devolve by blood. This being the case a husband cannot be heard to inherit his late wife's real property which she acquired from her family following the death of her parents because, the surviving husband is seen as a stranger to the family of his late wife. This rule found judicial support in Caulcrick v. Harding, ${ }^{3}$ where the deceased landowner left property for his three daughters, one of whom was the plaintiff's deceased wife. The plaintiff claimed a third share of the property by virtue of his deceased wife's right. The Plaintiff's action failed because he had no such right, not being a member of the wife's family.

Prior tothe Supreme Court decision in OnyiborAnekwe, Chinweze v. Mrs. Maria Nweke a widow is not entitled to share in the property of the deceased husband. The only saving grace is where she had occupied the apartment during the life time of her husband even if she had no child; yet she loses the right to continue to occupy the apartment if she eventually remarries to a man who is not the brother of her deceased husband; in which case, the late husband's family has the right to evict her from the family house ${ }^{5}$. The customary law argument is that, since inheritance devolves by blood, the wife not being originally of the husband's family had no right to inherit property from the family at the death of her husband. The Nigeria Supreme Court had declared this custom as barbaric, repugnant to natural justice, equity and good conscience ${ }^{6}$.

Prior tothe Supreme Court decision in Onyibor Anekwe, Chinweze v. Mrs. Maria Nweke the widow had no right to alienate her deceased husband's property absolutely. She may on moral ground be allowed to let out the property and use the proceeds to maintain herself in the absence of any maintenance allowance coming from her late husband's brothers? .

This custom has long faced criticisms from different quarters and had been adjudged to offend the principles of natural justice, equity, and good conscience. It is possible that a widow, during her marriage and during the deceased husband's life time, might have contributed more than the husband to purchase or build the house in question. It is therefore not only repugnant to natural justice equity and good conscience, but also amount to utter wickedness to deprive her the right of inheritance in the event of her husband's demise. Those who uphold this cultural discrimination against widows even in this $21^{\text {st }}$ century, with advent of modern civilization and international law are morally bankrupt to say the least or better put, insane.

Similarly the husband is not permitted to inherit the late wife anti nuptial property on the ground that he is also a stranger to the late wife's family. The only remedy is where the wife has surviving male children and the husband therefore inherits through the children. The second remedy is where the late wife acquired the property during the marriage. If the late wife had no male child, her anti nuptial property reverts back to her relatives, though the husband has a right over personal property. This was the decision in the case of Nwugege v. Adigwe. ${ }^{8}$

The property a woman acquired before her marriage is referred to an ante-nuptial property. Such property remains hers throughout her life time and if dies before her husband, the property devolves on her male children, and if she has no issues, but she predeceases her husband, her ante-nuptial property reverts to her biological family and never to her husband or to her husband's family. Her husband may have the grace of inheriting her personal property and not her real estate. The cultural philosophy behind this arrangement is that, devolution goes by blood and the husband not being an original member of the wife's family cannot inherit her ante-nuptial property. The inheritance of wife's property by her husband may occur if the wife'sante-nuptial property became mixed with that of her husband's property during the marriage.

In another scenario where, for instance, the wife and her husband and children are involved in an auto crash and she is the only survivor, in which case her husband and children predeceased her, the late husband's property, even if acquired by the husbandand wife, will be inherited by the husband's relatives. The wife's relatives in this circumstance have no cultural interest and rights in the late husband's property.

\section{Distribution of estate among the male off springs in Igbo land in the south eastern Nigeria}

As enunciated earlier, the females are not included in the distribution of the real and personal estateof a deceased father or head of the family. The mode of distribution of the estateof a deceased father or head of the family is not a static mode or formula. In some instances where the deceased had more than one wife, the property is

${ }^{1}$ Ejiamike v Ejiamike E.C.S.L.R 11, (1972)

${ }^{2}$ Onwusike v Onwusike 6 E.N.L.R p.18, (1962)

${ }^{3} 7$ NLR 48, (1926)

${ }^{4} 9$ NWLR (PT 1412) p.393-422, (2014)

${ }^{5}$ Nezianya $v$. Okagbue 1 All NLR p. 52, (1963)

${ }^{6}$ OnyborAnekwe, Chinweze v. Mrs. Maria Nweke 9 NWLR (PT 1412) p. 393-422, (2014)

${ }^{7}$ Nezianya v. Okagbue 1 All NLR p. 52, (1963)

${ }^{8} 11$ NLR p.134, (1934) 
usually distributed per stripes, that is, according to number of wives who are fortunate to have male children. In other situation, the distribution of per capita is applied, wherefore the estate is distributed according to the number of sons of the deceased man. Where distribution is per stripes, the distribution among each of the wife's male children is done in order of seniority, which also means that the eldest son takes a lion share, followed by the other sons according to the ages ${ }^{1}$. The female children are left out of the distribution.

Where distribution is percapita, the eldest son of the deceased polygamist takes first and of course takes more share than the other children, who would take shares according to order of seniority.

Who inherits a married woman's estate in Igbo land in the south eastern Nigeria?

A married woman may die and leave behind several real and personal estates. The male children inherit the real estate of their late mother. In the absence of a male child, the husband inherits her real estate acquired during the marriage. The late married woman's father or the father's successor does not inherit the deceased married woman's estate. In a case where the children and her husband predeceased the woman, the right of succession goes to her late husband's successor. However the anti-nuptial real property, which is acquired as a feme sole (single girl) by the married woman, will be inherited by her maiden family. ${ }^{2}$ The late married woman's female children do not get anything from the real estate of their late mother. The female children have the unchallenged right to inherit their late mother's clothing, ornaments, shoes, jewelries, hand bags, umbrellas, wristwatches, cooking utensils.

This seemingly marginalization of the females and widows in the Igbo land in the south eastern Nigeria had persisted for centuries. This situation is made worse where the so called only son or sons are wayward and irresponsible, yet they are still the ones to inherit their father's estates and their mother's landed properties she acquired as a married woman. Even where the female children proved more responsible and more educated, they have no right in their father's estate and their mother's landed properties.

Lately, in what appears to be a devine intervention, the Supreme Court of Nigeria had declared those cultures that exclude women and widows from inheritanceas being repugnant to natural justice, equity and good conscience. We shall analyse these cases with their facts to bring out their relevance to this discussion

1. Mrs LoisChituruUkeje

Administratrix of the estate of L.O Ukeje (Deceased)

2. Enyinnaya LazarusUkeje

Administrator of the estate of L.O Ukeje (Deceased) and for himself and on behalf of the other children of L.O Ukeje (except the Plaintiff)

Vs.

1. Miss Gladys Ada Ukeje, ${ }^{3}$

Summary of the facts are:

On 27th December 1981, one Mr. Lazarus Ogbonnaya Ukeje, a native of Umuahia in lmo State died intestate. He had a real property in Lagos State and for most of his life was resident in Lagos State. The first appellant got married to the deceased on $13^{\text {th }}$ December 1956. There are four children of the marriage. The respondent is not one of the four. After Lazarus Ogbonnaya Ukeje died, the first and second appellants (mother and son) obtained Letters of Administration for and over the deceased's estate. On being aware of this development, the Plaintiff/Respondent filed an action in court wherein she claimed to be a daughter of the deceased and by virtue of that fact had a right to partake in the sharing of her late father's estates. Her claims before a Lagos High Court were for:

1. A declaration that the plaintiff, as a daughter of one L.O. Ukeje (deceased), is the person entitled to the estate or one of the persons entitled to share in the estate of the said L.O. Ukeje (deceased).

2. An order that the grant of Letters of Administration dated $15^{\text {th }}$ June 1982 made to the first and second defendants in respect of the estate of the said L.O. Ukeje (deceased) be revoked and declaring the same to be null and void to all intents and purposes in law.

3. An order of injunction restraining the first and second defendants from administering the estate of the said L.O. Ukeje (deceased) and relying on the said letters of administration dated $15^{\text {th }}$ June 1982 granted to them and/or holding themselves out as Administrators of the said estate to members of the public and/or transacting any business with any person in respect of the said estate of the said L.O. Ukeje (deceased).

4. An order that the first and second defendants prepare an inventory of all and singular the estate and/or render account of all monies, transactions and/or properties which have come into their possession since the grant of the said letters of administration of the estate of Mr. L.O. Ukeje (deceased).

5. An order that the grant of letters of administration of the said L.O. Ukeje (deceased) be made to the plaintiff and the second defendant.

Pleadings were filed and exchanged. The statement of claim was filed on 22 February 1983, and the

${ }^{1}$ Nwogugu, E.I (supra) p. 406, ( 1974)

${ }^{2}$ Obi SNC (supra ) chapter 25, Nwogugu, E.I ( 1974) (supra) p. 410

${ }^{3} \mathrm{EJSC}$ (vol. 3) $147 \mathrm{SC}$, (2015) 
statement of defence on $27^{\text {th }}$ April 1983. The statement of defence was subsequently amended five times and finally on $18^{\text {th }}$ June, 1990. A reply to statement of defence was filed on $9^{\text {th }}$ November 1984 , amended on $15^{\text {th }}$ April, 1986 and $24^{\text {th }}$ November, 1986. The first witness, the plaintiff, gave evidence on $31^{\text {st }}$ May, 1984.

The plaintiff's case was closed after her mother concluded her evidence on $8^{\text {th }}$ November 1985 as PW2 Rhodes-Vivour JSC (Delivering the Lead Judgment): held thus below:

This appeal is on the paternity of the respondent; whether the respondent was a daughter of. O. Ukeje (deceased). L. O. Ukeje deceased is subject to the lgbo Customary Law. Agreeing with the High Court, the Court of Appeal correctly found that the Igbo native law and custom which disentitles a female from inheriting in her late father's estate is void as it conflicts with sections 39(1)(a) and (2) of the 1979 Constitution (as amended). This finding was affirmed by the Court of Appeal. There is no appeal on it. The findings remain inviolate.

Sections 39(1) (a) and (2) of the 1979 Constitution is now contained in the 1999 Constitution as section 42(1) (a); (2) and it states that:

"42(1) A citizen of Nigeria of a particular community, ethnic group, place of origin, sex, religion or political opinion shall not by reason only that he is such a person:

(a) Be subjected either expressly by, or in the practical application of, any law in force in Nigeria or any executive or administrative action of the government, to disabilities or restrictions to which citizens of Nigeria of other communities, ethnic groups, places of origin, sex, religion or political opinions are made subject: or ,.. No citizen of Nigeria shall be subjected to any disability or Deprivation merely by reason of the circumstances of his birth"

No matter the circumstances of the birth of a female child, such achild' is entitled to an inheritance from her late father's estate. Consequently, the Igbo customary law which disentitles a female child from partaking in the sharing of her deceased father's estate is in breach of section 42(1) and (2) of the Constitution.

The Justices delivering the lead judgment concluded and said, 'in the light of all that I have been saying, the appeal is dismissed.In thespirit of reconciliation parties to bear their own costs'

In another celebrated case of 1 . OnyborAnekwe, 2. Chinweze v. Mrs. Maria Nweke ${ }^{1}$ SC OGUNBIYI, J .S.C. (Delivering the Leading Judgment) held as follows: "The appeal before us, is against the judgment of the Court of Appeal, Enugu Division delivered on the 14"' day of February, 2013 wherein their Lordship, of that court in their wisdom dismissed the totality of the appellants' appeal and thereby upheld the judgment of the trial High Court Anambra State in granting the respondent's claim, in part and dismissed the appellants' counter-claim. The genesis of this case was that the respondent as plaintiff instituted the suit that led to this appeal before the Mbailinofu District of Anambra State Customary Court but subsequently transferred to the High Court upon the order made by Awka Division of Anambra State High Court on 19"' February, 1991.

In her amended statement of claim filed on 30"' May, 2000, the respondent herein as plaintiff at paragraph 26 sought the following reliefs against the defendants/now appellants.

"26. Whereof the plaintiff claims against the defendants jointly 'and severally as follows:

(a) A declaration that the plaintiff is the person entitled to statutory right of occupancy of piece or parcel of land which is situate at Amikwo village Awka and verged red in her plan No. TLD/ANO 1/92 and tiled with this statement of claim.

(b) An injunction restraining the defendants, their servants, and agents from further trespass on the said piece or parcel of land.

(c) An order of court compelling the 2"'" defendant to remove part of his building constructed into the plaintiff's land.

(d) An order of court compelling the defendants to share the Nwogbo Okonkwo Eli family lands averred in paragraph 16 of this statement of claim.

In the alternative, an account of the proceeds of the sale of the family lands and payment over to the plaintiff what is due to herand N500, 000(five hundred naira) general damages for trespass. In their amended statement of defence filed on $6^{\text {th }}$ February, 2007 the defendants denied the plaintiffs claim and also counter claimed for:

"A declaration that the defendants" father being entitled to the statutory right of occupancy over the piece or parcel of land the subject matter of this suit, the $1^{\text {st }}$ defendant being the 1 st son of his late father is now deemed to be entitled to statutory right of occupancy a over the same land in accordance with the native law and custom of Awka people"'

The supreme continued thus: "I hasten to add at this point that the custom and practices of Awka people upon which the appellants have relied for their counter claim is hereby out rightly condemned in very strong terms. In other words, a custom of this nature in the $21^{\text {st }}$ century societal setting will only tend to depict the

${ }^{1} 9$ NWLR (PT 1412) 393-422, (2014) 
absence of the realities of human civilization. It is punitive, uncivilized and only intended to protect the selfish perpetration of male dominance which is aimed at suppressing the right of the womenfolk in the given society. One would expect that the days of such obvious differential discrimination are over. Any culture that disinherits a daughter from her father's estate or wife from her husband's property by reason of God instituted gender differential should be punitively and decisively dealt with. The punishment should serve as a deterrent measure and ought to be meted out against the perpetrators of the culture and custom. For a widow of a man to be thrown out of her matrimonial home, where she had lived all her life with her late husband and children, by her late husband's brothers on the ground that she had no male child, is indeed very barbaric, worrying, and flesh skinning'.

'It is indeed much more disturbing especially where the counsel representing such perpetrating clients, though learned, appears comfortable in identifying, endorsing and also approving of such a demeaning custom,"OGUNBIYI, J .S.C concluded with tone of disapproval. In a similar circumstance as the case under consideration, this court in Nzekwu v. Nzekwe held amongst others and ruled "that theplaintiff had the right of possession of her late husband's propertyand no member of her husband's family has the right to dispose ofit or otherwise whilst one is still alive."

'The impropriety of such a custom which militates against women particularly, widows, who are denied their inheritance, deserves to be condemned as being repugnant to natural justice, equity and good conscience. The repulsive nature of the challenged custom is heightened further in the case at hand where the widow of the deceased is sought to be deprived of the very building where her late husband was buried. The condemnation of the appellants' act is in the circumstance without any hesitation or apology. The clarion call made by the appellants and asking that the lower court's judgment be upset cannot be acceded to. Consequently, the appellants' two issues raised in this appeal are both resolved against them. The appeal is without merit and is hereby dismissed while the judgment of the Court of Appeal, Enugu Division which affirmed that of the trial High Court Anambra State, Awka is hereby also affirmed by me. On the question of costs I will award a punitive sum of N200, 000.00k against the appellants and in favour of the respondent .Appeal is dismissed with costs of N200, 000.001 in favour ofthe respondent".

Several cultural critics hold the view that the Supreme Court is comprised of men who knew nothing about the cultural compositions and values of the Igbo people in the south eastern Nigeria; hence the justices of the Supreme Court of Nigeria merely took advantage of their position to destroy the age long cherished customs of the Igbo origin. The argument may sound logical on the surface; but the proponents of this view point are also blind to the fact that the provision of section 42 of the 1999 Constitution of the Federal Republic of Nigeria upon which the justices based their decision was not passed into the law by the Supreme Court of Nigeria. All the Supreme Court did was simply to interpret and apply the law in a given suit before them.

On our humble view as authors of this article, we also agree completely that the Igbo people practice of denying the females and widows the right to inheritance of real estate and succession is inhuman, stupid and nonsensically borne out of greed on the part of the male folks. Such inhuman discriminatory gender culture must not be allowed to continue.

Recommendations towards ensuring that the Igbo people in the south eastern Nigeria comply with the above decisions of the Supreme Court as regards the rights of females and widows to inheritance of real estates of their late parents and deceased husbands respectively.

1. We recommends that the Supreme Court decisions in Ukeje v. Ukeje (2015) EJSC (vol. 3) 147 SC; 1. Onybor Anekwe, 2. Chinweze v. Mrs. Maria Nweke (2014) 9 NWLR (PT 1412) 393-422; Nzekwu v. Nzekwe (1989) 3 SCNJ page 167; (1989)2 NWLR (Pt. 104) 373be mandatorily incorporated into the constitutions of every Igbo Association such as Ohaneze Ndigbo, town unions, council of chiefs and elders, Age grades etc. this measure if taken will be reminding the Igbos of the importance of those apex court landmark judgments, failure to comply with the decisions will amount to contempt. ' 'Those decisions will longer be a hear say as it has been enshrined into their constitutions

2. The right of the female child to inheritance among the Igbo nation shouldbe domesticated, that is, passed into law by the Houses of assembly of the south easternstates of Nigeria and the penalty be made fourteen (14) years imprisonmentwithout option of fine for convicts.

3. Radio and television broadcast be carried out frequently to sensitize the people on these heroic Supreme Court decisions. This will ensure that everybody in the in the south eastern Nigeria will be aware of these decisions. They will also be made to know the consequence of contempt of court for failure to abide by these decisions whenever a similar decision is handed down in future. Ignorance of the judgments may make people not to follow the new trend in allowing females the right to inheritance.

4. Religious bodies such as federation of Catholic lawyers of Nigeria, Christian

13 SCNJ page 167; (1989) 2 NWLR (Pt. 104) 373, (1989) 
Association of Nigeria (CAN) Eastern Nigeria chapters, Pentecostal fellowship

of Nigeria (PFN) Eastern Nigeria chapter must take the challenge as agents of socialization to sensitize the Igbo people of the injustice inherent in denying females and widows theirconstitutional right to inheritance. People usually obey their clergies, so the religious bodies have a duty to sensitize their followers.

5. We also recommend that the husband ought to have the right to inherit the wife anti nuptial property, since by marriage the two have become one. Whatever one had acquired before and during overture should belongto both as family property in every situations.It should also be passed into law by the Houses of assembly of the south eastern states of Nigeria, granting the husband the right to inherit his deceased wife's ant nuptial properties. What is good for the geese is also good for the gender.

6. We also recommend that, apart from granting a daughter the right to inherit the real estate of her late father, a woman should also be given the right to succeed her deceased father as the head of family in a situation where the daughter is the eldest child among the surviving children. There is nothing wrong in it. It happens in other jurisdiction, for instance among the Yoruba nation of Nigeria.

We would conclude by asserting that, this Igbo culture of denying a widow the right to inherit her matrimonial property where she had lived all her life with her late husband and children, by her late husband's brothers, on the ground that she had no male child is bad and inhuman; it indeed very barbaric, worrying and flesh skinning. Or a situation where a daughter is completely excluded from the inheritance of her late father's estate is also a barbaric and demeaning culture which, in the twenty first century must not be allowed to continue. Every meaningful human being must lend his voice against this hopeless, useless and barbaric culture. Now is the time for positive action and for progress of mankind in general. 